\title{
High-Power-Density Power Conversion Systems for HVDC-Connected Offshore Wind Farms
}

\author{
Amir Parastar ${ }^{*}$ and Jul-Ki Seok ${ }^{\dagger}$ \\ ${ }^{*}$ Power Conversion Lab., Dept. of Electrical Eng., Yeungnam University, Gyeongsan, Korea
}

\begin{abstract}
Offshore wind farms are rapidly growing owing to their comparatively more stable wind conditions than onshore and land-based wind farms. The power capacity of offshore wind turbines has been increased to $5 \mathrm{MW}$ in order to capture a larger amount of wind energy, which results in an increase of each component's size. Furthermore, the weight of the marine turbine components installed in the nacelle directly influences the total mechanical design, as well as the operation and maintenance (O\&M) costs. A reduction in the weight of the nacelle allows for cost-effective tower and foundation structures. On the other hand, longer transmission distances from an offshore wind turbine to the load leads to higher energy losses. In this regard, DC transmission is more useful than AC transmission in terms of efficiency because no reactive power is generated/consumed by DC transmission cables. This paper describes some of the challenges and difficulties faced in designing high-power-density power conversion systems (HPDPCSs) for offshore wind turbines. A new approach for high gain/high voltage systems is introduced using transformerless power conversion technologies. Finally, the proposed converter is evaluated in terms of step-up conversion ratio, device number, modulation, and costs.
\end{abstract}

Key words: Offshore wind turbine, Power conversion system, Power density, Transformerless topology

\section{INTRODUCTION}

Offshore 5-10MW marine turbines become more attractive for the wind power industry. Particularly, they increase efficiency and reduce generation costs, compared to previous wind turbine technologies [1], [2]. Offshore behemoths will make current technology inappropriate due to increased wind turbine component weights such as bulky and complex generators, transformers, and converters. Therefore, wind turbine manufacturers are attempting to create an optimal design for large marine turbines. The optimized design would allow for reducing the component volumes and weights, O\&M costs, and power losses, hence increasing power density, reliability, and efficiency of wind turbines.

On the other hand, high-voltage DC (HVDC) cables are more applicable in offshore wind farms because of the increased size of wind parks and the longer distance to shore. According to

Manuscript received Feb. 21, 2013; revised Jun. 10, 2013

Recommended for publication by Guest Associate Editor Yongsug Suh.

${ }^{\dagger}$ Corresponding Author: doljk@yu.ac.kr

Tel: +82-53-810-2484, Yeungnam University

*Power Conversion Lab., Dept. of Electrical Eng., Yeungnam University, Gyeongsan, Korea
[3], high-voltage AC (HVAC) systems lead to the lowest transmission losses for distances of up to $55-70 \mathrm{~km}$ depending on the size of the wind parks. For longer distances, HVDC transmission has the lowest transmission losses.

The voltage level of most large wind turbines are usually in the low-voltage (LV) range of 400-690 $\mathrm{V}$ due to voltage limitations of power electronics devices and safety regulations [1]. In LV systems, a high current flowing through long cables induces a significant $\mathrm{I}^{2} \mathrm{R}$ loss. In order to cope with increasing power losses and cabling costs, a line-frequency (50 or $60 \mathrm{~Hz}$ ) step-up transformer is required to interface with a medium voltage (MV) network, which is typically $25-40 \mathrm{kV}$. Nonetheless, this solution causes a considerable increase in weight and volume that leads to higher installation costs.

Full-bridge isolated conversion systems have been widely used for higher-voltage gains. By replacing the bulky $50 / 60 \mathrm{~Hz}$ transformers in these systems with higher-frequency transformers, a great HPDPCS can be obtained [4]-[6]. However, its extendibility to the MW range requires extremely challenging transformer designs using the latest-generation magnetic material, which is an enormous expense. Moreover, the reduction in size usually implies an increased loss density in the transformer, which demands notable thermal management efforts [7]. 
TABLE I

COMPARISON OF TOP 10 Wind TuRbine ManufacturEs In 2011

\begin{tabular}{|c|c|c|c|c|c|c|}
\hline $\begin{array}{l}\text { Market sha } \\
\text { re } 2011 \\
(2010) \%\end{array}$ & $\begin{array}{l}\text { Manufacturer } \\
\text { (country) }\end{array}$ & $\begin{array}{l}\text { Turbine } \\
\text { type }\end{array}$ & Generator & $\begin{array}{l}\text { Power } \\
\text { rating } \\
(\mathrm{MW})\end{array}$ & $\begin{array}{l}\text { Output } \\
\text { voltage } \\
\text { (V) }\end{array}$ & $\begin{array}{l}\text { Grid } \\
\text { connection }\end{array}$ \\
\hline $12.7(14.8)$ & Vestas (Denmark) & V164-7.0MW & PMSG & 7.0 & 690 & $\begin{array}{l}\text { Full power } \\
\text { converter }\end{array}$ \\
\hline $9.0(11.1)$ & Sinovel (China) & SL6000 & DFIG & 6.0 & 690 & $\begin{array}{l}\text { Full power } \\
\text { converter }\end{array}$ \\
\hline $8.7(9.5)$ & Goldwind (China) & GW3000 & PMSG & 3.0 & 690 & $\begin{array}{l}\text { Full power } \\
\text { converter }\end{array}$ \\
\hline $8.0(6.6)$ & Gamesa (Spain) & G128-5MW & PMSG & 5 & 690 & $\begin{array}{l}\text { Full power } \\
\text { converter }\end{array}$ \\
\hline $7.8(7.2)$ & $\begin{array}{l}\text { Enercon } \\
\text { (Germany) }\end{array}$ & E-126/7.5 & EESG & 7.5 & 400 & $\begin{array}{l}\text { Full power } \\
\text { converter }\end{array}$ \\
\hline $7.7(9.6)$ & GE (US) & $4.1-113$ & PMSG & 4.1 & 690 & $\begin{array}{l}\text { Full power } \\
\text { converter }\end{array}$ \\
\hline $7.6(6.9)$ & Suzlon(India) & S9X & DFIG & 2.1 & 690 & $\begin{array}{l}\text { Direct } \\
\text { connection }\end{array}$ \\
\hline $7.4(4.2)$ & $\begin{array}{l}\text { Guodian United } \\
\text { Power (China) }\end{array}$ & UP3000-100 & N/A & 3.0 & 690 & N/A \\
\hline $6.3(5.9)$ & $\begin{array}{l}\text { Siemens } \\
\text { (Germany) }\end{array}$ & SWT-6.0 & PMSG & 6.0 & 690 & $\begin{array}{l}\text { Full power } \\
\text { converter }\end{array}$ \\
\hline $3.6(\mathrm{NA})$ & $\begin{array}{l}\text { Mingyang Wind } \\
\text { Power (China) }\end{array}$ & SCD3.0MW & PMSG & 3.0 & 620 & $\begin{array}{l}\text { Full power } \\
\text { converter }\end{array}$ \\
\hline
\end{tabular}

To overcome increasing power losses and maintain a high power density, it is expected that large marine turbines will require a higher-voltage level without transformers [1]. Single-module DC/DC boost converters are theoretically able to produce infinitely high conversion ratios. However, the maximum gain is practically limited by different circuit imperfections, such as parasitic elements [8]. Multiple-module boost converters offer a potential for large gains because of the multiplicative effect, compared to single-module boost converters. A transformerless multiple-module DC/DC boost converter tends to feature a high power density, high efficiency, and high reliability at locations that are often far from land-based facilities to decrease the installation and O\&M costs [9].

This paper presents a comprehensive study of the HPDPCSs for offshore wind turbines. First, the main characteristics of wind turbines such as the output power rating, grid connection, and output voltage are explained. The main electrical components of wind turbines are considered for the design of the HPDPCSs. Second, transformerless power conversion topologies are represented with the introduction of isolated power conversion systems. Finally, a new transformerless power conversion system is proposed to overcome the aforementioned topology drawbacks. The proposed converter is evaluated for the step-up conversion ratio, device numbers, modulation, and costs. The cascade configuration is compared to an $\mathrm{AC} / \mathrm{DC}$ series-connected converter to demonstrate its advantages in HV high-gain offshore wind applications.

\section{WIND TURBINE AND POWER CONVERSION SYSTEM CHARACTERISTICS}

The characteristics of the top 10 wind turbine manufacturers in 2011 are presented in Table I [10]. Each wind turbine manufacturer has several products with different output power levels. Therefore, only the products with the highest power level are compared. Table I includes the manufacturer, generator type, output power, output voltage, and grid connection type that are obtained from companies' websites. It can be seen that most manufacturers employ permanent magnet synchronous generators (PMSGs) to improve power density, controllability, and reliability, especially in unexpected situations like grid faults [11]. The maximum power rating in the current market is $7.5 \mathrm{MW}$. It should be noted that the aim is always to maximize the power level of a wind turbine to reduce generation costs, particularly in offshore wind farms. All of the 


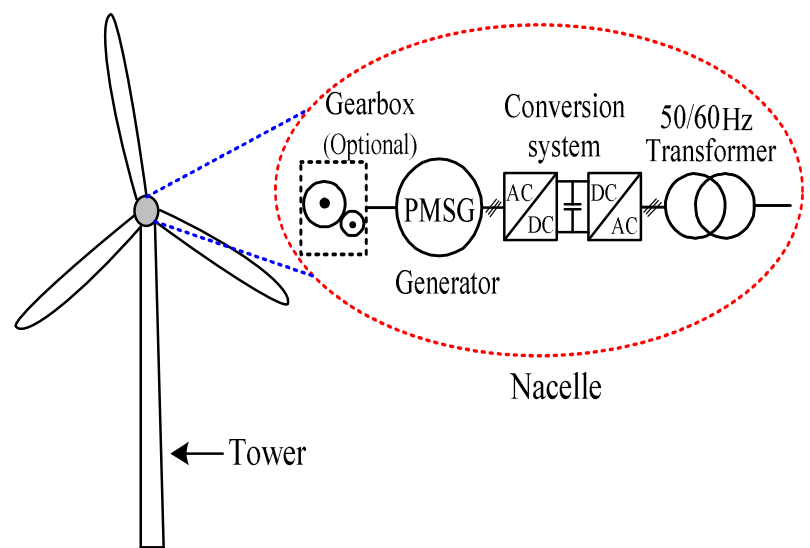

Fig. 1. Schematic of a wind turbine topology.

generators typically have relatively LV levels of 400-690 V. However, some manufacturers such as Repower systems $\mathrm{GmbH}$ in Germany; have a higher voltage of $6.6 \mathrm{kVAC}$ [12]. This voltage level will reduce the stator winding currents, particularly in high-power wind turbines. The generator and converter systems are usually in a nacelle on the top of a tower, while a grid step-up transformer is placed in the base of the tower (or in the nacelle). Some companies place the AC/DC converter in the nacelle and the DC/AC converter in the base of the tower to decrease power losses in the wind turbine [13]. A simplified representation of a wind turbine is shown in Fig. 1.

It can be observed that the generator, transformer, and converter are three main electrical components in a wind turbine. The general specification of a $3 \mathrm{MW}$ wind turbine (V90-3.0 MW) indicates that the weights of the generator, convertor, and $50 / 60 \mathrm{~Hz}$ transformer are 8.5 ton, 2.5 ton, and 8 ton, respectively [14]. They are the heaviest electrical components in a wind turbine system. These heavy electrical components create serious issues as they must be taken to the sites where the offshore wind turbines are located. Thus the offshore wind turbines should cope with the following challenges to make the HPDPCSs a feasible alternative.

Fig. 2 shows the development trends for an optimal design of a high-power conversion system in offshore wind energy systems. Bulky and huge electrical components represent high investment costs due to difficult erection and equipment transportation from shore to the installation sites. If high-power-density electrical components are utilized in offshore wind farms, offshore floating platforms can be fully assembled and installed with a reduced burden for large vessels and time spent at sea [15]. There is a greater need for high reliability owing to the inherent lack of turbine access at sea which makes O\&M more difficult. Smaller stages of conversion and lower device counts mean lower costs, fewer failure points, and lower power losses. Hence a power conversion system should feature a high power density, high efficiency, high reliability, and low costs.

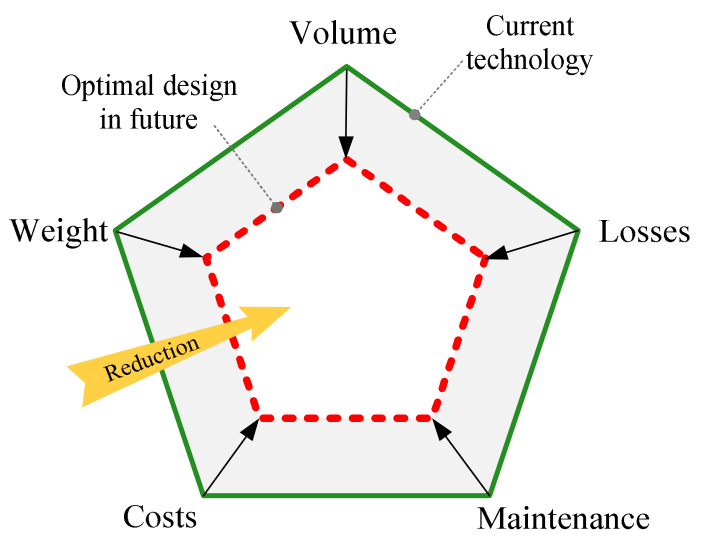

Fig. 2. Development trends in power conversion systems for offshore wind turbines.

\section{ISOLATED POWER CONVERSION SYSTEMS FOR OFFSHORE WIND TURBINES}

This section demonstrates $\mathrm{AC} / \mathrm{DC}$ power converters with a $\mathrm{HF}$ transformer. Here, the combination of an AC/DC converter and a HF transformer is called an isolated power conversion system.

\section{A. AC/DC Power Converter Topologies}

Full-bridge isolated conversion systems have been widely used for HV gains. These systems rely on a HF transformer to gain a high-power-density converter. In [16], a dual active bridge converter with a triangular modulation and a series resonant converter with a constant frequency modulation were designed, where both can achieve zero-current-switching for the HV side. Here, a $1 \mathrm{MW}, 1.2 \mathrm{kV}$ to $12 \mathrm{kV}$ converter was evaluated. The selected switching frequency is $20 \mathrm{kHz}$ in order to reduce the size of the transformer. If an SiC JFET is taken as an LV side switch, an efficiency of $98 \%$ can be achieved. However, each power device is composed of more than one hundred single SiC JFETs connected in parallel and series to reach the available current and voltage rating. The power conversion system in a wind turbine is shown in Fig. 3. Several HF transformers with different core shapes were represented and evaluated for power losses and power density. A HF transformer with a shell-type core has the highest power density of $285.71\left(\mathrm{~kW} / \mathrm{dm}^{3}\right)$ (weight power density $(\mathrm{kW} / \mathrm{kg}$ ) for $20 \mathrm{kHz}, 1 \mathrm{MW}$ transformer is 20 times the $50 / 60 \mathrm{~Hz}$ transformer [6]) and the efficiency is measured up to $99.66 \%$. For this design, the chosen HF transformer core material is nanocrystalline.

In [17], a new direct $\mathrm{AC} / \mathrm{AC}$ power converter was introduced that fulfills the aforementioned requirements of Fig. 2 owing to fewer stages of conversion, the use of a HF transformer, and the absence of a bulky electrolyte capacitor (see Fig. 3 and Fig. 4). The power conversion system consists of a three-phase AC to a single-phase AC converter, a HF 


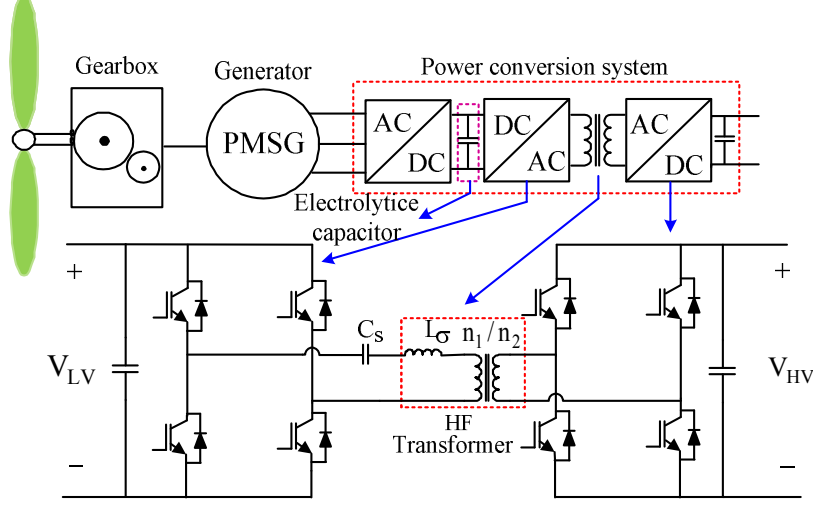

Fig. 3. Power conversion system for a wind turbine in [16].

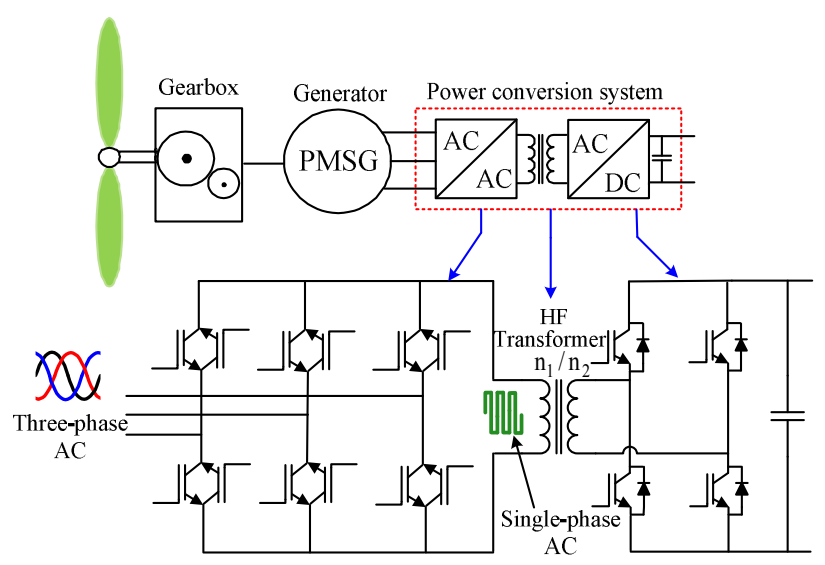

Fig. 4. Wind energy conversion system with converter topology in [17].

transformer, and a single-phase full-bridge AC-DC converter. The AC/AC converter is based on bidirectional switches with reverse-blocking IGBTs and the switches are controlled with a dedicated switching pattern. However, the HF high-power transformer design and the experimental results were not discussed.

\section{B. High-Frequency High-Power Transformer Design}

A HF high-power transformer is suggested between two converters to electrically isolate the LV side from the HV grid and to step-up the voltage to reduce the power losses in a wind turbine. HF transformers are used in a wide range of low-power applications. The main issues to consider are the losses, weight and leakage inductance in high-power applications. The weight of a transformer is lower with higher-frequencies, but a smaller size makes the cooling design of the electrical parts tougher. Isolated DC/DC conversion systems usually require inductances in series with the transformer winding to achieve zero-voltage-switching conditions. This inductance defines the power transfer capability of the system and thus its value should be carefully selected. In order to increase the power density of the converter,

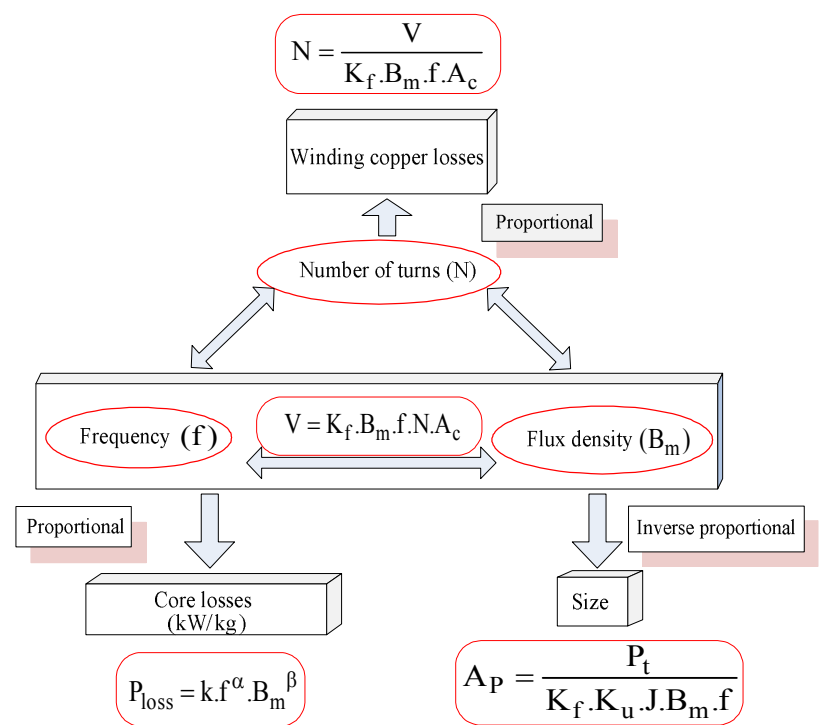

Fig. 5. Trade-offs diagram between frequency, flux density and number of turns.

this series inductance is often magnetically integrated as the leakage inductance $\mathrm{L}_{\sigma}$ of the transformer (see Fig. 3).

Fig. 5 shows the trade-offs between the physical variables such as the frequency $f$, maximum flux density $B_{m}$, and number of turns $\mathrm{N}$ (a periodic voltage applied to a coil with an effective cross-sectional area $A_{c}$ and a coefficient waveform $K_{f}$, where the average applied voltage is given: $\left.V=K_{f} \cdot B_{m} \cdot f \cdot N \cdot A_{c}\right)$ in the design of HF transformers. The power losses include the core, copper, and dielectric losses. The copper losses are dependent on $\mathrm{L}_{\sigma}$ which is mainly due to the eddy current effect of the conductors and $\mathrm{N}$. The core losses depend on the hysteresis and eddy current losses that are increased with $\mathrm{f}$ and $\mathrm{B}_{\mathrm{m}}$. From Fig. 5, it can be seen that $\mathrm{f}$ and $\mathrm{B}_{\mathrm{m}}$ have a complex and nonlinear relationship with the core, copper losses, and $\mathrm{N}$. Thus HF transformer design requires thorough and careful consideration in order to ensure an optimized electrical and magnetic utilization [4], [7]. Important issues such as the core material consideration, the core configuration, the winding arrangement, and the thermal management are described as follows.

1) Core Material Consideration: The physical parameters such as $B_{m}$ and $f$ of the core material have a great impact on the power density and efficiency of the transformer. In [18], a relationship between the area product $A_{p}\left(A_{p}\right.$ is the product of the core window area $A_{w}$ multiplied by $A_{c}$ as illustrated in Fig. 6) and the power handling capability $P_{t}$ in a transformer is represented as

$$
\mathrm{P}_{\mathrm{t}}=\mathrm{K}_{\mathrm{f}} \cdot \mathrm{K}_{\mathrm{u}} \cdot \mathrm{J} \cdot \mathrm{f} \cdot \mathrm{B}_{\mathrm{m}} \cdot \mathrm{A}_{\mathrm{p}},
$$

where $\mathrm{K}_{\mathrm{u}}$ and $\mathrm{J}$ are the window utilization factor and the current density, respectively. The current density for a given temperature rise and the total weight $\mathrm{W}_{\mathrm{t}}$ of a transformer can be related to $A_{p}$. The equations are expressed as 


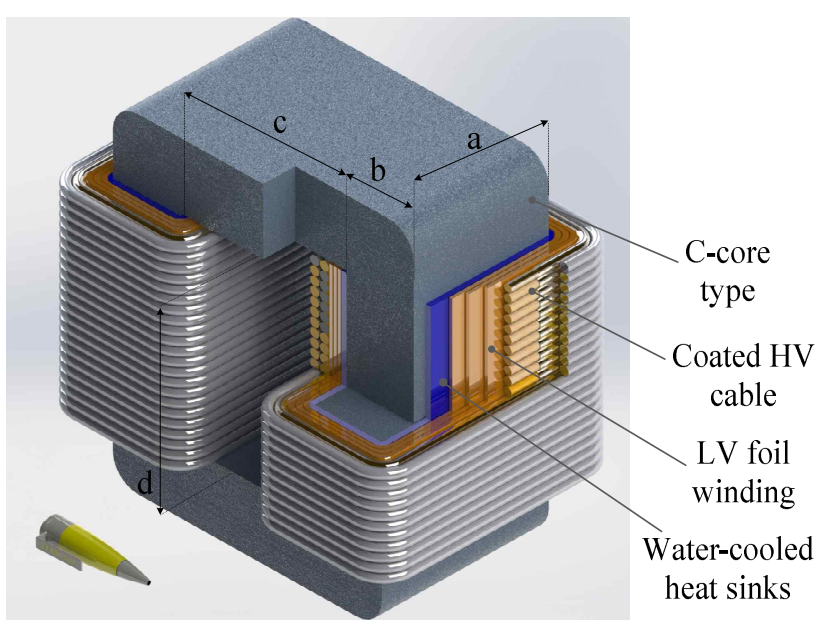

Fig. 6. HF high-power C-core-type transformer. (Cross-sectional area $A_{c}=a \times b$, Core window area $A_{w}=c \times d$ and Area product $A_{p}=A_{c} \times A_{w}$.

$$
\begin{gathered}
\mathrm{J}=\mathrm{K}_{\mathrm{j}} \mathrm{A}_{\mathrm{p}}^{\mathrm{x}}, \\
\mathrm{W}_{\mathrm{t}}=\mathrm{K}_{\mathrm{w}} \mathrm{A}_{\mathrm{p}}^{0.75},
\end{gathered}
$$

where $K_{j}, x$, and $K_{w}$ are constant values and depend on the core type. Then, substituting (2) and (3) into (1) yields the power handling capability as

$$
P_{t}=K_{u} \cdot K_{f} \cdot K_{j} \cdot f \cdot B_{m} \cdot\left(K_{w}{ }^{-1} \cdot W_{t}\right)^{0.75(x+1)} \text {. }
$$

Table II demonstrates the core type constants for temperature increases of $25^{\circ} \mathrm{C}$ and $50^{\circ} \mathrm{C}$. Fig. 7 shows a power handling capability comparison between the powder and non-powder core types. It can be observed that the powder cores have a higher power density $(\mathrm{kw} / \mathrm{kg})$, compared to the non-powder cores. However, the non-powder cores are cheaper and make core losses lower. A list of the most commonly used non-powder cores in HF applications is represented in Table III.

As can be seen, the selected materials present high saturation fluxes and low core losses, especially in the case of nanocrystalline materials with a saturation flux of $1.23 \mathrm{~T}$ and core losses $\left(\right.$ at $\mathrm{B}_{\mathrm{m}}=1 \mathrm{~T}$ and $\left.\mathrm{f}=20 \mathrm{kHz}\right)$ in the range of 0.08 $\mathrm{kW} / \mathrm{kg}$ to $0.14 \mathrm{~kW} / \mathrm{kg}$ (core losses are evaluated using Steinmetz equation $\mathrm{P}_{\text {loss }}=\mathrm{k} \cdot \mathrm{f}^{\alpha} \cdot \mathrm{B}_{\mathrm{m}}^{\beta}$ where $\mathrm{k}, \alpha$, and $\beta$ are determined by the material characteristics and usually obtained from the manufacturer's datasheet). Some manufactures make silicon steel laminations with gauges down to 0.001 inches, for reducing the eddy current loss, that are suitable for $\mathrm{HF}$ applications. However, their core losses are very high compared to nanocrystaline materials.

Fig. 8 compares the frequency and flux density limitations for nanocystaline, amorphous, and silicon steel materials at same maximum core losses. It can be seen that the nanocrystaline, amorphous, and silicon steel core materials have operating frequencies $20 \mathrm{kHz}, 5 \mathrm{kHz}$, and $2.5 \mathrm{kHz}$, respectively. Thus nanocrystalline materials with a high

\begin{tabular}{|c|c|c|c|c|}
\hline Core type & $\begin{array}{l}\mathrm{K}_{\mathrm{j}} \\
\Delta \mathrm{T}=25^{\circ} \mathrm{C}\end{array}$ & $\begin{array}{l}\mathrm{K}_{\mathrm{j}} \\
\Delta \mathrm{T}=50^{\circ} \mathrm{C}\end{array}$ & $x$ & $\mathrm{~K}_{\mathrm{w}}$ \\
\hline Powder & 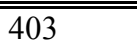 & 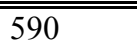 & "-0.12 & "58.5 \\
\hline $\begin{array}{l}\text { Non-powder } \\
\text { (Lamination } \\
\& \text { Tape) }\end{array}$ & 322 & 468 & -0.14 & 66.5 \\
\hline
\end{tabular}

TABLE II

Core Type Constants [19]

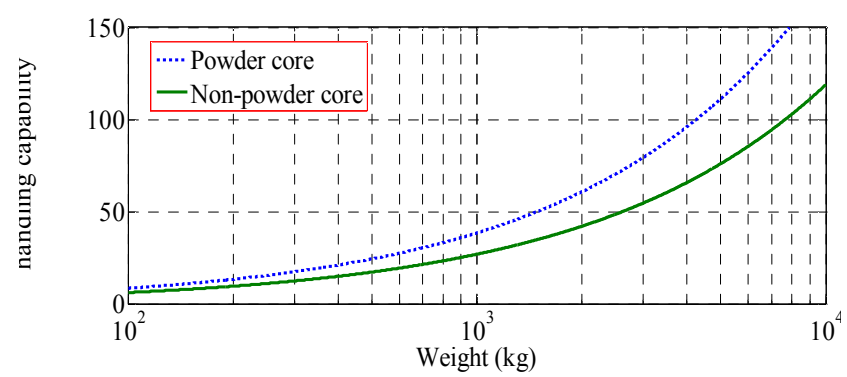

Fig. 7. Normalized power handling capability comparison between powder and non-powder cores for $\Delta \mathrm{T}=50^{\circ} \mathrm{C}$.

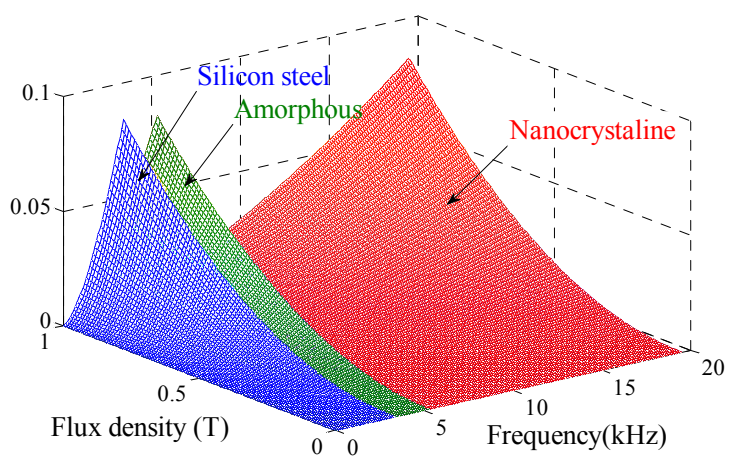

Fig. 8. Core losses in terms of frequency and flux density.

TABLE III

\begin{tabular}{|c|c|c|c|c|c|}
\hline $\begin{array}{l}\text { Non- } \\
\text { powder } \\
\text { core }\end{array}$ & Types & $\begin{array}{l}\text { Sat. } \\
\text { flux } \\
(\mathrm{T})\end{array}$ & $\begin{array}{l}\text { Core } \\
\text { losses } \\
(\mathrm{kW} / \mathrm{Kg})\end{array}$ & Cost & Manufac. \\
\hline \multirow{3}{*}{ Amorphous } & $\begin{array}{l}\text { Microlite } \\
(2605 \mathrm{SA} 1)\end{array}$ & 1.56 & 1.5 & \multirow{3}{*}{$\begin{array}{c}\text { medi- } \\
\text { um }\end{array}$} & $\begin{array}{l}\text { Metglas } \\
{[19]}\end{array}$ \\
\hline & $\begin{array}{l}\text { Powerlite } \\
\text { (260SA1) }\end{array}$ & 1.56 & 0.59 & & Metglas \\
\hline & Namglass 1 & 1.59 & 0.66 & & $\begin{array}{l}\text { Magnetic } \\
\text { metal }[20]\end{array}$ \\
\hline \multirow{2}{*}{$\begin{array}{l}\text { Nano- } \\
\text { crystaline }\end{array}$} & $\begin{array}{l}\text { Finemet } \\
\text { (FT-3M) }\end{array}$ & 1.23 & 0.14 & \multirow{2}{*}{ high } & $\begin{array}{l}\text { Hitachi } \\
{[21]}\end{array}$ \\
\hline & Namglass 4 & 1.23 & 0.08 & & $\begin{array}{l}\text { Magnetic } \\
\text { metal }\end{array}$ \\
\hline $\begin{array}{l}\text { Silicon } \\
\text { steel }\end{array}$ & $\begin{array}{l}3 \% \text { Grain } \\
\text { oriented }\end{array}$ & 2 & 1.36 & low & $\begin{array}{l}\text { Magnetic } \\
\text { metal }\end{array}$ \\
\hline
\end{tabular}

Non-POWder Core MATERIALS CONSIDEREd IN High FREQUENCY

saturation and low core losses are more suitable in high-power applications. Despite the great quality performance of the nanocrystalline materials, their cost is 
very high due to their manufacturing processes (see Table III).

2) Core Configuration: Two popular configurations are used to design HF transformers: shell-type and C-core-type transformers. A C-core type transformer is shown in Fig. 6. In the shell-type transformer, the core is built with two pairs of C-cores arranged in E-core configuration. The shell-type transformer has $15 \%$ more magnetic material (longer mean path length), whereas it has a $36 \%$ less winding part (shorter mean length of winding), compared to the C-core type.

3) Winding Arrangement: The LV winding is built with thick copper foils to achieve a higher power density. The HV winding is built with a strand HV cable. However, by using a HV cable, there exists a double isolation level between each HV turn as shown in Fig. 6. This issue leads to an increase in the core size and a lower power density. A litz wire can be used in the HV side to gain a triple power density, compared to the HV cables for the HF transformer design [16].

4) Thermal Management: Water-cooled heat sinks can be placed between the core and the LV winding surface as illustrated in Fig. 6. Another proposed heat extraction mechanism consists of using a braided hollow copper conductor with an internal plastic hose carrying water.

\section{TRANSFORMERLESS POWER CONVERSION SYSTEMS}

This section describes the feasibility of transformerless power conversion systems for offshore wind turbines. Recently, research efforts have turned to the design of two kinds of generators in a transformerless offshore wind turbine. The first involves generators which operate on MV levels $(10-40 \mathrm{kV})$ using MV cables for the stator windings [1], [22]. For such a system, an HV three-phase converter is utilized for the grid connection [22]. The second involves generators that operate on LV levels as mentioned in Section II. They require a boost converter to interface with an MV network, which is typically $25-40 \mathrm{kV}$. A full discussion of these conversion systems is beyond the scope of this paper and further information for each topology is available in [22]-[25].

\section{A. Transformerless Power Conversion Topologies}

A transformerless, step-up, highly-reliable, and compact converter system would be an attractive solution for large-scale offshore wind turbines as mentioned in Section II. In order to get enough HV gains, multiple-module topologies connected to DC grids have been suggested. In [23], an AC/DC series-connected converter system suitable for direct-drive wind turbines was presented. Direct-drive axial flux PM machines can achieve a high power density in wind turbine systems [26], [27]. They overcome the need for a gearbox with its associated maintenance demands. In this design, AC/DC two-level converters are used and they reach an acceptable total

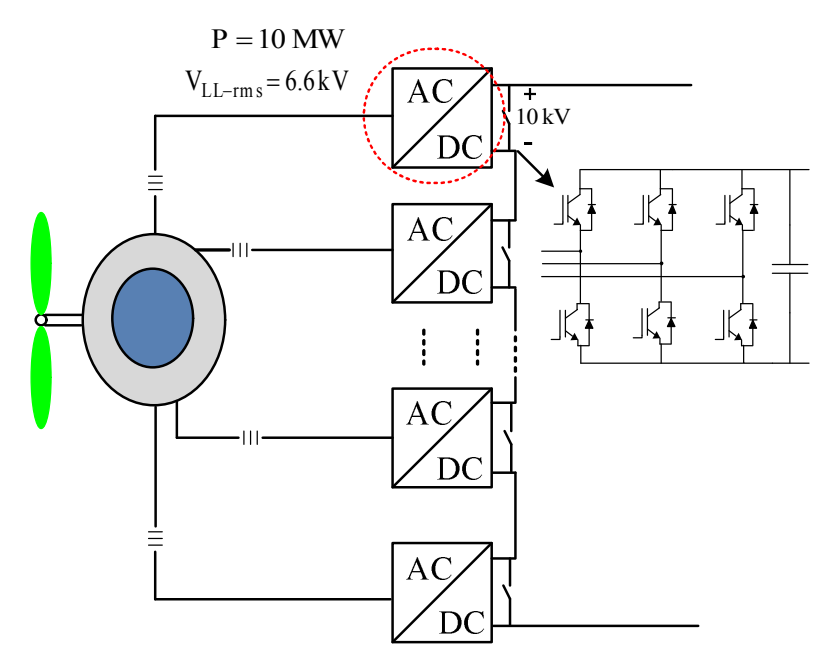

Fig. 9. Generator-drive topology in [23].

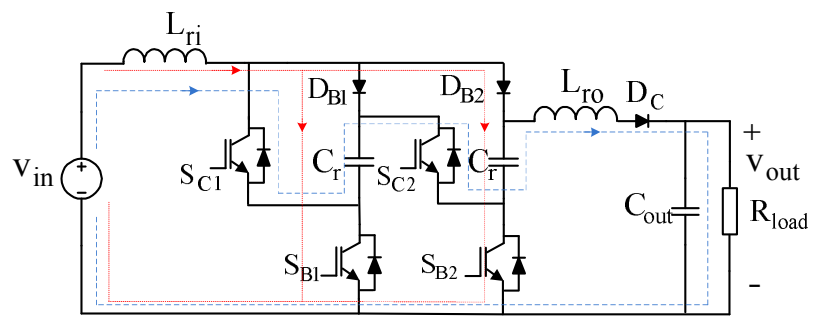

Fig. 10. Proposed DC/DC converter.

DC-grid voltage due to the number of modules made by the multi-winding generator design. Fig. 9 shows its power circuit connection. Nine modules are required to make $100 \mathrm{kV}$ in an HVDC grid. Each module uses six IGBT switches in this topology.

A similar concept was represented in [25]. This transformerless system consists of four AC/DC three-level neutral point clamped (NPC) converters, with the DC-links connected in series. The reported voltage is $23.6 \mathrm{kV}$ in the $\mathrm{MV}$ grid side. Each conversion module has an output voltage of $5900 \mathrm{~V}$ DC that is made by $4500 \mathrm{~V}$ class IGCTs. A hybrid boost or buck/boost converter was proposed to achieve a high conversion ratio for offshore wind farms applications [9]. Nonetheless, because the duty ratio of the main switch is very large for achieving a high-voltage gain, the switching frequency is relatively low to reduce losses and get enough turn-off time for the switches. Hence increasing the size of the passive elements, such as the boost inductors and filter capacitors, is inevitable due to the low switching frequency.

\section{B. Proposed Transformerless Power Conversion System}

Recently, the common types of switched-capacitor converters based on the Marx generator topology are considered as an attractive solution to meet requirements such as a high power density and control simplicity. The Marx generator is capable of achieving $\mathrm{HV}$ boost ratios and is suitable for high pulsed-power technologies [28], [29]. 


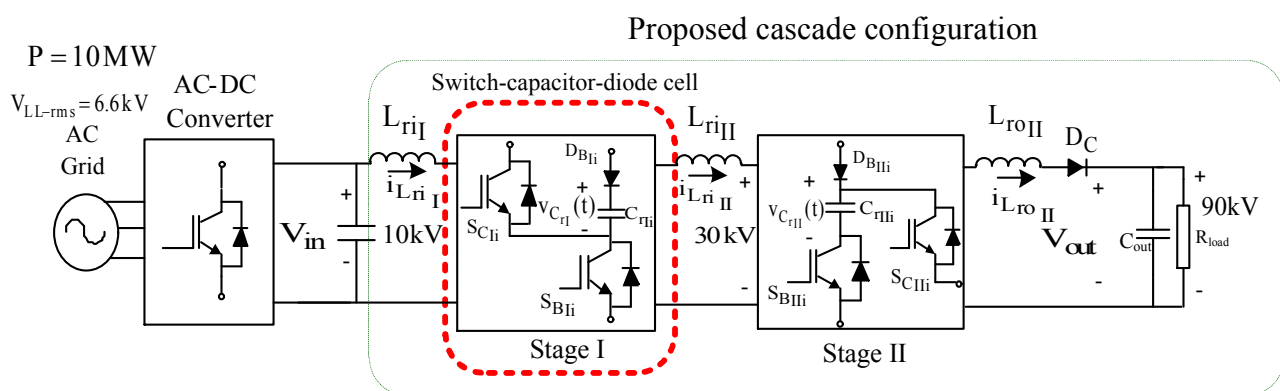

Fig. 11. Proposed DC/DC cascade converter with two stages.

The proposed $\mathrm{DC} / \mathrm{DC}$ converter is characterized by resonant switching transitions to achieve minimal switching losses and maximum system efficiency in high power applications. An appropriate output capacitor size is considered to eliminate output voltage ripples and to work as a charge storage. A simplified circuit of the proposed converter is shown in Fig. 10. This topology includes two resonant capacitors $\mathrm{C}_{\mathrm{r}} \mathrm{s}$, an output capacitor $\mathrm{C}_{\mathrm{out}}$, an input resonant inductor $\mathrm{L}_{\mathrm{r}}$, an output resonant inductor $\mathrm{L}_{\mathrm{ro}}$, three diodes $\mathrm{D}_{\mathrm{B} 1}, \mathrm{D}_{\mathrm{B} 2}$, and $\mathrm{D}_{\mathrm{C}}$, and four switches $\mathrm{S}_{\mathrm{B} 1}, \mathrm{~S}_{\mathrm{B} 2}, \mathrm{~S}_{\mathrm{C} 1}$, and $\mathrm{S}_{\mathrm{C} 2}$. At the steady-state, in the charging mode (see the red dotted lines in Fig. 10), $\mathrm{S}_{\mathrm{B} 1}$ and $\mathrm{S}_{\mathrm{B} 2}$ are turned $\mathrm{ON}$ while $\mathrm{S}_{\mathrm{C} 1}$ and $\mathrm{S}_{\mathrm{C} 2}$ are turned OFF. Therefore, $\mathrm{L}_{\mathrm{ri}}$ and $\mathrm{C}_{\mathrm{r}} \mathrm{s}$ are charged through a resonant phenomenon. In the discharging mode (see the blue dashed lines in Fig. 10), while $\mathrm{S}_{\mathrm{C} 1}$ and $\mathrm{S}_{\mathrm{C} 2}$ are turned $\mathrm{ON}, \mathrm{S}_{\mathrm{B} 1}$ and $\mathrm{S}_{\mathrm{B} 2}$ are OFF. It should be noted that three times the input-voltage is sequenced when $\mathrm{S}_{\mathrm{C} 1}$ and $\mathrm{S}_{\mathrm{C} 2}$ are connected to the voltage source, resonant inductors, and charged resonant capacitors in series to the output load. Here, both the switching-ON and switching-OFF instants qualify as soft-switching so that switching losses are minimal. At the steady-state, the converter gain is defined as

$$
\frac{\mathrm{V}_{\text {out }}}{\mathrm{V}_{\text {in }}}=(\mathrm{n}+1) \text {, }
$$

where $\mathrm{n}$ is the number of resonant capacitors.

Offshore wind farms grids in the MW range must interface with $\mathrm{HV}$ power systems. In order to cope with this situation, a cascade configuration is introduced to achieve a higher voltage gain and a high rated power. The use of a multiple-module converter has an advantage in terms of maintenance and reliability at locations that are often far from land-based facilities. Fig. 11 shows the cascade configuration of the proposed DC/DC converter with two stages. The voltage gain can be expressed as

$$
\frac{\mathrm{V}_{\text {out }}}{\mathrm{V}_{\text {in }}}=9
$$

A full bridge $\mathrm{AC} / \mathrm{DC}$ converter supplies a constant input $\mathrm{DC}$ voltage to the proposed cascade converter. A $10-\mathrm{MW}$ wind turbine with an output of $6.6 \mathrm{kV}_{\mathrm{LL}, \mathrm{rms}}$ is considered as an input source. This voltage will be boosted to $90 \mathrm{kV}$ for HVDC transmission through the proposed DC/DC converter as shown

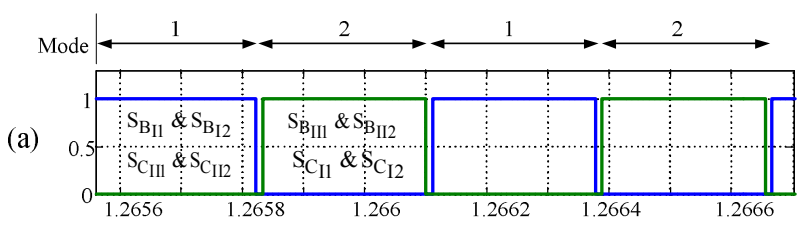

(b)
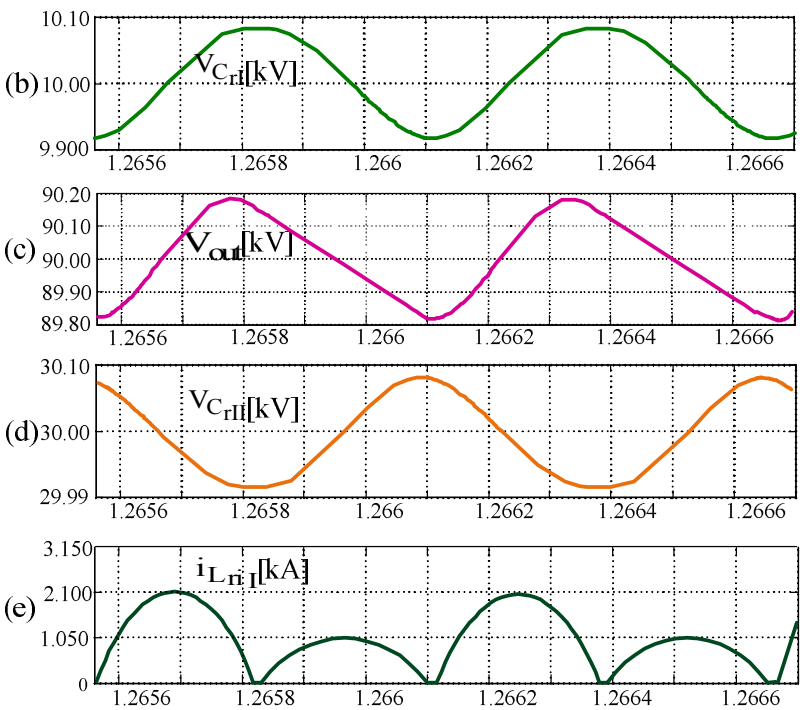

(f)

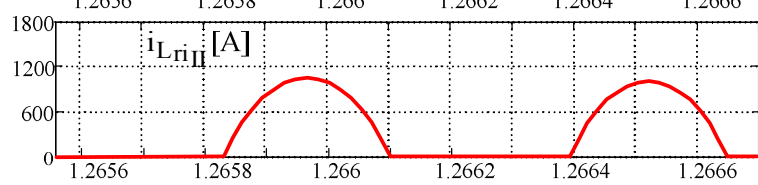

(g)

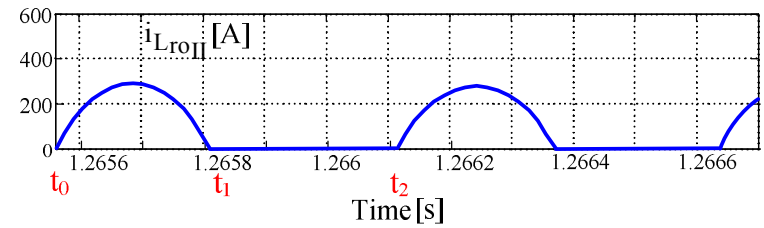

Fig. 12. Key simulation waveforms of resonant inductor currents, resonant capacitor voltages and output voltage under steady-state.

in Fig. 11. Here, stages I and II include two resonant capacitors $\mathrm{C}_{\mathrm{rI}} \mathrm{S}$ and three resonant capacitors $\mathrm{C}_{\mathrm{rII}} \mathrm{S}$, respectively.

Mode $1\left[t_{0}, t_{t}\right]$ : At the beginning of this mode $\left(\mathrm{t}=\mathrm{t}_{0}\right), \mathrm{S}_{\mathrm{BI}}$, $\mathrm{S}_{\mathrm{BI} 2}, \mathrm{~S}_{\mathrm{CII} 1}$, and $\mathrm{S}_{\mathrm{CII} 2}$ are $\mathrm{ON}$ while $\mathrm{S}_{\mathrm{CI} 1}, \mathrm{~S}_{\mathrm{CI} 2}, \mathrm{~S}_{\mathrm{BII} 1}$, and $\mathrm{S}_{\mathrm{BII} 2}$ are OFF as shown in Fig. 12(a). Therefore, $\mathrm{L}_{\text {ril }}$ and two $\mathrm{C}_{\mathrm{rI}} \mathrm{S}$ are charged whereas $\mathrm{L}_{\mathrm{roII}}$ and three $\mathrm{C}_{\mathrm{rII}} \mathrm{S}$ are discharged $\left(\mathrm{C}_{\mathrm{rII}} \mathrm{S}\right.$ were previously charged by $\mathrm{C}_{\mathrm{rl}} \mathrm{S}$ in Mode 2) through a resonant 


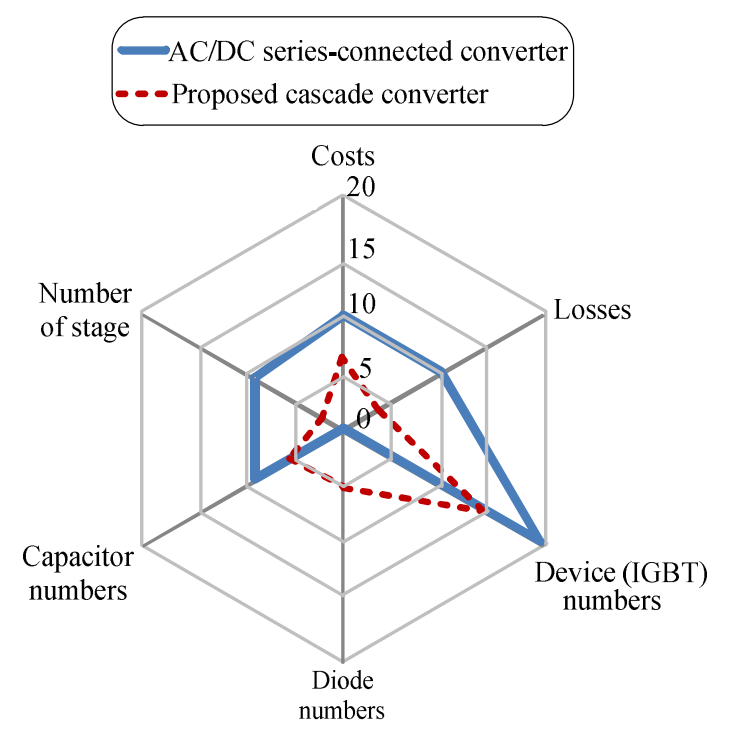

Fig. 13. Normalized comparisons of HVDC converters: device counts, costs, losses and number of stages.

phenomenon in stages I and II, respectively (see Fig. 12(b) and (d)). At the time $\mathrm{t}_{1}, \mathrm{C}_{\mathrm{rI}} \mathrm{S}$ are charged up to the $10 \mathrm{kV}$ level (input voltage level). It should be noted that nine times the input voltage $(90 \mathrm{kV})$ is sequenced when $\mathrm{S}_{\mathrm{CII} 1}$ and $\mathrm{S}_{\mathrm{CI} 2}$ are series connected with $\mathrm{L}_{\text {roII }}$, and $\mathrm{C}_{\mathrm{rII}} \mathrm{S}$ to charge $\mathrm{C}_{\text {out }}$ as depicted in Figs. 11 and 12(c). Therefore, the proposed cascade converter offers the potential for a large voltage-gain because of the multiplicative effect. Then, $\mathrm{S}_{\mathrm{BI} 1}, \mathrm{~S}_{\mathrm{BI} 2}, \mathrm{~S}_{\mathrm{CII} 1}$, and $\mathrm{S}_{\mathrm{CII} 2}$ can be OFF under the zero-current condition as shown in Fig. 12(e) and (g).

Mode $2\left[t_{1}, t_{2}\right]$ : At time $\mathrm{t}_{1}, \mathrm{~S}_{\mathrm{Cl} 1}, \mathrm{~S}_{\mathrm{Cl} 2}, \mathrm{~S}_{\mathrm{BII} 1}$, and $\mathrm{S}_{\mathrm{BII} 2}$ are turned $\mathrm{ON}$, while $\mathrm{S}_{\mathrm{BI} 1}, \mathrm{~S}_{\mathrm{BI} 2}, \mathrm{~S}_{\mathrm{CII} 1}$, and $\mathrm{S}_{\mathrm{CII} 2}$ are OFF. Then, $\mathrm{C}_{\mathrm{rI}} \mathrm{S}$ are series connected with $\mathrm{L}_{\text {ril }}, \mathrm{L}_{\text {rill }}$, and stage II to charge $\mathrm{C}_{\mathrm{rII}} \mathrm{S}$ through a resonant condition (see Fig. 12(d)). During this interval, (refer to the output side that is isolated by a reversed biased $\mathrm{D}_{\mathrm{C}}$ ), the previously charged $\mathrm{C}_{\text {out }}$ is discharged by $\mathrm{R}_{\text {load }}$. At $\mathrm{t}=\mathrm{t}_{2}, \mathrm{~S}_{\mathrm{CI} 1}, \mathrm{~S}_{\mathrm{CI} 2}, \mathrm{~S}_{\mathrm{BII} 1}$, and $\mathrm{S}_{\mathrm{BII} 2}$ become OFF under the zero-current condition (see Fig. 12(e) and (g)).

Here, the proposed cascade converter is evaluated against the $\mathrm{AC} / \mathrm{DC}$ series-connected converter in [23]. The $\mathrm{AC} / \mathrm{DC}$ series-connected approach includes nine modular two-level converters. The maximum output DC voltage of each of the two-level converters is 1.51 times the input voltage as shown in Fig. 9.

Each switch or diode is made up of several series and parallel-connected devices to withstand the rated current and voltage. These converters are compared based on the following features: 1) number of stages; 2) device numbers; 3) costs; and 4) losses. Normalized comparisons of the converters are depicted in Fig. 13. It can be observed that device counts, losses, and costs are significantly reduced for the proposed power conversion system. The AC/DC series-connected approach requires 220 switches $(6.5 \mathrm{kV}-250 \mathrm{~A})$, whereas the proposed topology uses only 180 switches $(6.5 \mathrm{kV}-250 \mathrm{~A})$. A lower device count simplifies the implementation by decreasing the balancing network components used with the series-connected devices. A lower device count means lower costs, fewer failure points and higher reliability. The soft-switching action is provided by the resonant condition of the proposed topology, compared with the hard-switching technique in the AC/DC series-connected approach. Thus the switching losses are minimal and the overall system size can be reduced by increasing the switching frequency. These results are in good agreement with the aforementioned requirements of Fig. 2 in Section II. Therefore, the proposed converter is superior to the AC/DC series-connected approach owing to lower costs and higher efficiency. Therefore, the multiple-module cascade approach is well suited for high-power high-gain offshore wind applications.

\section{CONCLUSIONS}

In this paper, several high-power-density power conversion systems are presented for offshore wind turbines in MV levels. Isolated and transformerless power conversion systems are illustrated for offshore wind turbines. Full bridge isolated conversion systems with a high-frequency transformer achieve a high-voltage gain and a high power density. However, high-frequency transformers with large turn ratios are difficult to design large-scale offshore wind turbines. Then, a new transformerless DC/DC boost converter is proposed and the proposed cascade converter is compared to the AC/DC series-connected converter. The cascade configuration makes the proposed converter a feasible option for high-voltage and high-power offshore wind applications that require a high power density, high reliability, and high efficiency.

\section{ACKNOWLEDGMENT}

This research was supported by the 2012 Yeungnam University Research Grants.

\section{REFERENCES}

[1] X. Yuan, J. Chai, and Y. Li, "A transformerless high-power converter for large permanent magnet wind generator systems," IEEE Trans. Sustainable Energy, Vol. 3, No. 3, pp. 318-329, Jul. 2012.

[2] K. Ma and F. Blaabjerg, "Multilevel converters for 10 MW wind turbines," in Proc. IEEE-EPE, pp. 1-10, 2011.

[3] P. Bresesti, W. L. Kling, R. L. Hendriks, and R. Vailati, "HVDC connection of offshore wind farms to the transmission system," IEEE Trans. Energy Convers., Vol. 22, No. 1, pp. 37-43, Mar. 2007.

[4] G. Ortiz, J. Biela, and J. W. Kolar, "Optimized design of medium frequency transformers with high isolation requirements," in Proc. IEEE-IECON, pp. 631-638, 2010.

[5] A. Parsai, J. S. Yim, D. Divan, A. Bendre, and S. K. Sul, "A new architecture for offshore wind farms," IEEE Trans. 
Power Electron., Vol. 23, No. 3, pp. 1198-1204, May 2008.

[6] K. Hatua, S. Dutta, A. Tripathi, S. Baek, G. Karimi, and S. Bhattacharya, "Transformerless intelligent power substation design with $15 \mathrm{kV} \mathrm{SiC}$ IGBT for grid interconnection," in Proc. IEEE-ECCE, pp. 4225-4232, 2011.

[7] S. Meier, T. Kjellqvist, S. Norrga, and H. P. Nee, "Design considerations for medium-frequency power transformers in offshore wind farms," in Proc. IEEE-EPE, pp. 1-12, 2009.

[8] I. Laird and D. D. Chuan Lu, "High step-up DC/DC topology and MPPT algorithm for use with a thermoelectric generator," IEEE Trans. Power Electron., Vol. 28, No. 7, pp. 3147-3157, Jul. 2013.

[9] N. Denniston, A. Massoud, S. Ahmed, and P. Enjeti, "Multiple-module high-gain high-voltage DC-DC transformers for offshore wind energy systems," IEEE Trans. Power Electron., Vol. 58, No. 5, pp. 1877-1886, May 2011.

[10] [Online] Available: http://www.reachargenews.com

[11] F. Blaabjerg and Z. Chen, Power Electronics for Modern Wind Turbines, Morgan \& Claypool Publishers, Chap. 4, 2006.

[12] [Online]. Available: http://www.repower.uk.co.uk/en

[13] [Online]. Available: http://www.energy.siemens.com

[14] [Online]. Available: http://www.vestas.com

[15] Large-scale offshore wind power in the United States. [online]. Available: http:// www.nrel.gov/wind

[16] G. Ortiz, J. Biela, and J. W. Kolar, "1 megawatt, $20 \mathrm{kHz}$, isolated, bidirectional $12 \mathrm{kV}$ to $1.2 \mathrm{kV}$ DC-DC converter for renewable energy applications," in Proc. IEEE-ICPE, pp. 3212-3219, 2010

[17] A. Garces and M. Molinas, "A study of efficiency in a reduced matrix converter for offshore wind farms," IEEE Trans. Power Electron., Vol. 59, No. 1, pp. 184-192, Jan. 2012.

[18] C. Wm and T. Mclyman, "Transformer and inductor design handbook," Marcel Dekker, Chap. 5, 2004.

[19] [Online]. Available: http://metglas.com

[20] [Online]. Available: http:// www. magmet.com

[21] [Online]. Available: http://www.hitachimetals.co.jp

[22] M. Leijon, M. Dahlgren, L. Walfridsson, L. Ming, and A. Jaksts, "A recent development in the electrical insulation systems of generators and transformers" IEEE Elect. Insul. Mag., Vol. 17, No. 3, pp. 10-15, May/Jun. 2001.

[23] S. Gjerde, P. K. Olsen, and T. Undeland "A $10 \mathrm{MW}$ transformer-less, $100 \mathrm{kV}$ DC output, light weight electric drive for offshore wind power: Part II - the converter," in Proc. IEEE-ECCE, pp. 247-252, 2012.

[24] C. H. Ng, M. A. Parker, L. Ran, P. J. Tavner, J. R. Bumby, and E. Spooner, "A multilevel modular converter for a large lightweight wind turbine generator," IEEE Trans. Power Electron., Vol. 23, No. 3, pp. 1062-1074, May 2008.

[25] M. Carmeli, F. Castelli-Dezza, G. Marchegiani, M. Mauri, and D. Rosati, "Design and analysis of a medium voltage DC wind farm with a transformerless wind turbine generator," in Proc. IEEE-ICEM, pp. 1-6, 2010.

[26] S. Kahourzade, A. Gandomkar, A. Mahmoudi, N. Abd Rahim, W. P. Hew, and M. N. Uddin, "Design optimization and analysis of AFPM synchronous machine incorporating power density, thermal analysis, and back-EMF THD," Progress In Electromagnetics Research, Vol. 136, pp. 327-367, Jan. 2013.
[27] E. Spooner, P. Gordon, J. R. Bumby, and C. D. French "Lightweight ironless-stator PM generators for direct-drive wind turbines," IET Electr. Power Appl., Vol. 152, No. 1, pp. 17-26, Jan. 2005.

[28] L. M. Redondo and J. F. Silva, "Repetitive high-voltage solid-state Marx modulator design for various load conditions," IEEE Trans. Plasma Sci., Vol. 37, No. 8, pp. 1632-1637, Aug. 2009.

[29] L. M. Redondo, H. Canacsinh and J. F. Silva, "Generalized solid-state Marx modulator topology," IEEE Trans. Dielectr. Electr. Insul., Vol. 16, No. 4, pp. 1037-1042, Aug. 2009.

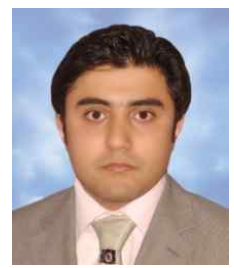

Amir Parastar received his B.S. and M.S. from the Department of Electrical Engineering, Islamic Azad University, Science and Research Branch, Tehran, Iran, in 2008. He is currently working toward his Ph.D. in the Power Conversion Laboratory, Department of Electrical Engineering, Yeungnam University, Gyeongsan, Korea. His current research interests include high-power DC/DC conversion systems and power converter control of offshore wind farms.

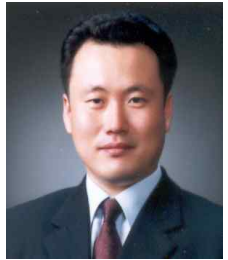

Jul-Ki Seok received his B.S., M.S., and $\mathrm{Ph} . \mathrm{D}$. in Electrical Engineering from Seoul National University, Seoul, Korea, in 1992, 1994, and 1998, respectively. From 1998 to 2001, he was a Senior Engineer with the Production Engineering Center, Samsung Electronics, Suwon, Korea. Since 2001, he has been a member of the faculty of the School of Electrical Engineering, Yeungnam University, Gyeongsan, Korea, where he is currently a Professor. His current research interests include motor drives, power converter control of offshore wind farms, and nonlinear system identification related to the power electronics field. Dr. Seok serves as the Chair of the IEEE Industry Applications Society (IAS) Industrial Drive Committee Paper Award Sub-Committee, as an Associate Editor of the IEEE Transactions on Industry Applications, and on the Editorial Board of the IET Electric Power Applications. 